\title{
The dividend policy of a company as an instrument of the long-term sustainability and a measure of the corporate responsibility
}

\author{
Tatiana Slepneva ${ }^{*}$, Maria Shalneva, and Sergei Balandin \\ Financial University under the Government of the Russian Federation, Leningradsky prospect, 49, \\ 125993 Moscow, Russia
}

\begin{abstract}
Current crisis caused by a lockdown puts many challenges on every corporation. In a situation of an unprecedently low demand in many spheres of business it is essential for companies to stay sustainable. Another key trend of the year 2020 is social unrest. Customers and partners expect companies to follow generally accepted companies responsibility principles. For companies one of the key instruments that can address both these issues is its dividend policy. This article describes how the leading Russian private O\&G company Lukoil uses its new dividend policy to overcome the challenges.
\end{abstract}

\section{Introduction}

The effect of the dividend policy for a company's sustainability is hard to overestimate. In a current situation of a low demand caused by a lockdown dividend policy is one of the few effective instruments available for a management. Dividend policy is especially important for a large company with a long tradition of high dividend payments. One of the leading companies in Russia that operates on a shrinking Q\&G market and has a long story of high dividend payments is Lukoil, which is why its case are of a great interest.

\section{Methods of the dividend policy}

For Lukoil effective dividend policy has always been a key instrument to sustainable development. It is especially important in a turbulence period [1]. To evaluate the effectiveness of the dividend policy, it is necessary to determine the goals that management sets when determining the dividend policy. The company declares the following approach to the dividend policy on its official website: "Paying competitive dividends to the company's shareholders has historically been a priority of PJSC LUKOIL. The company has been continuously increasing its dividend per share for the past 20 years"[2].

To determine whether the actual situation corresponds to the actual situation, we will analyze all available dividend payments of the company that have been made since its creation.

\footnotetext{
*Corresponding author: taslepneva@fa.ru
} 
First, it is worth noting that the company has used various types of shares throughout its existence, and therefore, it is necessary to separate the policies implemented within each type.

In the period 1994-2000, LUKOIL offered its shareholders to become owners of preferred shares. Table 1 shows information about payouts for this type of shares[3].

Table 1. Payments on preferred shares of PJSC LUKOIL

\begin{tabular}{|c|c|c|}
\hline Dividend period & Record date & Dividend per share (DPS) in rub \\
\hline 31.12 .2000 & 14.05 .2001 & 59,16 \\
\hline 31.12 .1999 & 24.04 .2000 & 17,45 \\
\hline 31.12 .1998 & 14.05 .1999 & 2,67 \\
\hline 31.12 .1997 & 20.04 .1998 & 0,91 \\
\hline 31.12 .1996 & 07.04 .1997 & 1 \\
\hline 31.12 .1995 & 20.04 .1996 & 0.5 \\
\hline 31.12 .1994 & 20.04 .1995 & 0.5 \\
\hline
\end{tabular}

Based on the payments, it can be argued that the company did not actually change the declared principles, constantly increasing the amount of dividends. The only exception is the year 1998. At the moment, the purchase of preferred shares of LUKOIL is not provided. Only ordinary shares of the company are represented on the free-float market.

Let's turn to payments on ordinary shares, the history of which began on December 31 , 1994. Table 2 provides data on accruals of dividends in the specified periods[3].

Table 2. Payments on ordinary shares of PJSC LUKOIL

\begin{tabular}{|c|c|c|}
\hline Dividend period & Record date & Dividend per share (DPS) in rub \\
\hline 31.12 .2019 & & 350 \\
\hline 30.09 .2019 & 21.12.2019 & 192 \\
\hline 21.12 .2018 & 09.06 .2019 & 155 \\
\hline 30.09 .2018 & 21.12 .2018 & 95 \\
\hline 31.12 .2017 & 11.07 .2018 & 130 \\
\hline 30.09 .2017 & 22.12 .2017 & 85 \\
\hline 31.12 .2016 & 10.07 .2017 & 120 \\
\hline 30.09 .2016 & 23.12 .2016 & 75 \\
\hline 31.12 .2015 & 12.07 .2016 & 112 \\
\hline 30.09 .2015 & 24.12 .2015 & 65 \\
\hline 31.12 .2014 & 12.06 .2015 & 94 \\
\hline 30.09 .2014 & 26.12 .2014 & 60 \\
\hline 31.12 .2013 & 15.07 .2014 & 60 \\
\hline 31.12 .2012 & 13.05 .2013 & 50 \\
\hline 31.12 .2011 & 11.05 .2012 & 75 \\
\hline 31.12 .2010 & 06.05 .2011 & 59 \\
\hline 31.12 .2009 & 07.05 .2010 & 52 \\
\hline 31.12 .2008 & 08.05 .2009 & 50 \\
\hline 31.12 .2007 & 08.05 .2008 & 42 \\
\hline 31.12 .2006 & 11.05 .2007 & 38 \\
\hline 31.12 .2005 & 11.05 .2006 & 33 \\
\hline 31.12 .2004 & 12.05 .2005 & 28 \\
\hline 31.12 .2003 & 07.05 .2004 & 24 \\
\hline 31.12 .2002 & 12.05 .2003 & 19,50 \\
\hline 31.12 .2001 & 08.05 .2002 & 15 \\
\hline
\end{tabular}


Continuation of Table 2. Payments on ordinary shares of PJSC LUKOIL

\begin{tabular}{|c|c|c|}
\hline 31.12 .2000 & 14.05 .2001 & 8 \\
\hline 31.12 .1999 & 24.04 .2000 & 3 \\
\hline 31.12 .1998 & 14.05 .1999 & 0,25 \\
\hline 31.12 .1997 & 20.04 .1998 & 0,22 \\
\hline 31.12 .1996 & 07.04 .1997 & 0,3 \\
\hline 31.12 .1995 & 20.04 .1996 & 0,2 \\
\hline 31.12 .1994 & 20.04 .1995 & 0,5 \\
\hline
\end{tabular}

Based on the company's dividend payment data, you can first see the change in the dividend policy that occurred on January 1, 2014. The new regulation on the dividend policy has established double dividend payments. Dividends were paid based on the results of nine months (a smaller part) and final annual dividends (a larger part). The total annual amount of dividends is shown in Fig. 1[4].

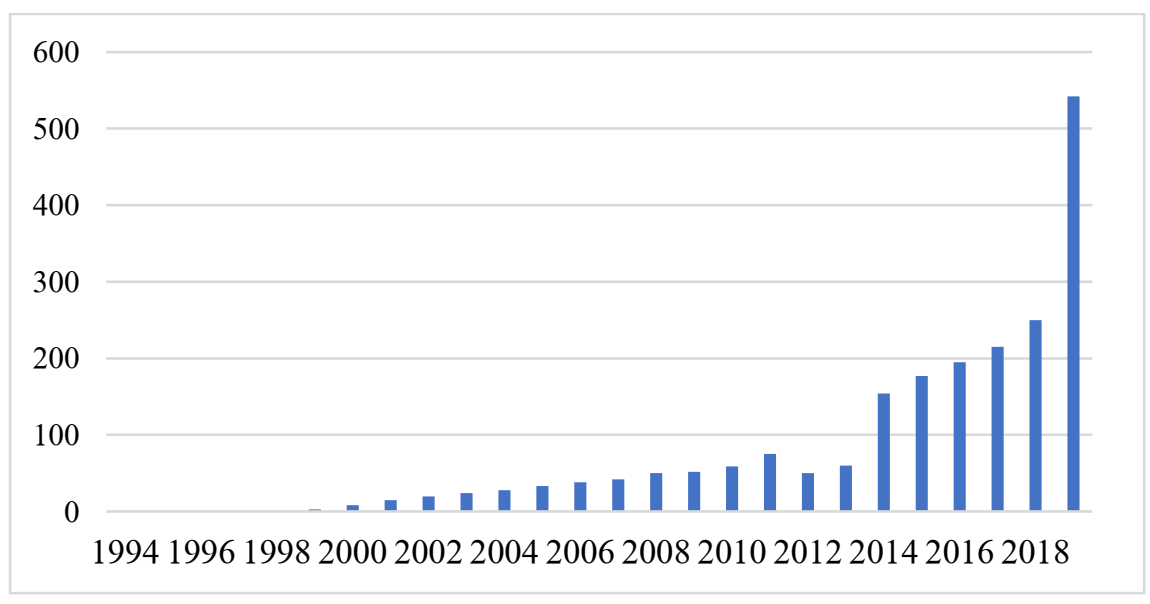

Fig.1. Total annual amount of dividends, RUB per share

You can see that the company's promise of constant growth in dividend payments is generally being fulfilled. Exceptions are 1995, 1997, and 2012.

In 2018, the regulation on a new dividend policy was adopted, which provides for the allocation of all free cash flow to dividends. The company declares an "opportunistic approach" to share repurchases. According to the President of PJSC LUKOIL, Vagit Alikperov, this is "a comprehensive effective solution that allows to achieve revenue growth for shareholders, and for the company additional flexibility in terms of reinvestment of capital, opportunities to improve its structure, as well as to maintain a balanced structure of shareholders"[5]. The advantages of this approach also include full transparency in the calculation of dividends.

A significant increase in dividend payments in 2019 is due to the change in LUKOIL's dividend policy adopted by the Board of Directors on October 16, 2019 [6]. The main changes in the dividend policy include the following:

1. The total amount of dividends on the company's outstanding shares, net of shares held by LUKOIL Group entities, is at least $100 \%$ of the company's adjusted free cash flow.

2. Adjusted free cash flow is calculated based on the CONSOLIDATED financial statements of PJSC LUKOIL prepared in accordance with IFRS and is defined as net cash received from operating activities, net of capital expenditures, interest paid, repayment of lease obligations, and expenses for the purchase of shares in PJSC LUKOIL.

3. The dividend per ordinary share is rounded to a multiple of one Russian ruble. 
4. Dividends are paid twice a year, and the amount of the interim dividend is calculated based on the consolidated financial statements for 6 months.

When analyzing dividend payments, it should be taken into account that LUKOIL seeks to increase only the absolute amount of the dividend. However, it is advisable to compare the dividends paid relative to the market value of the shares. The percentage return on shares is shown in Figure 2.

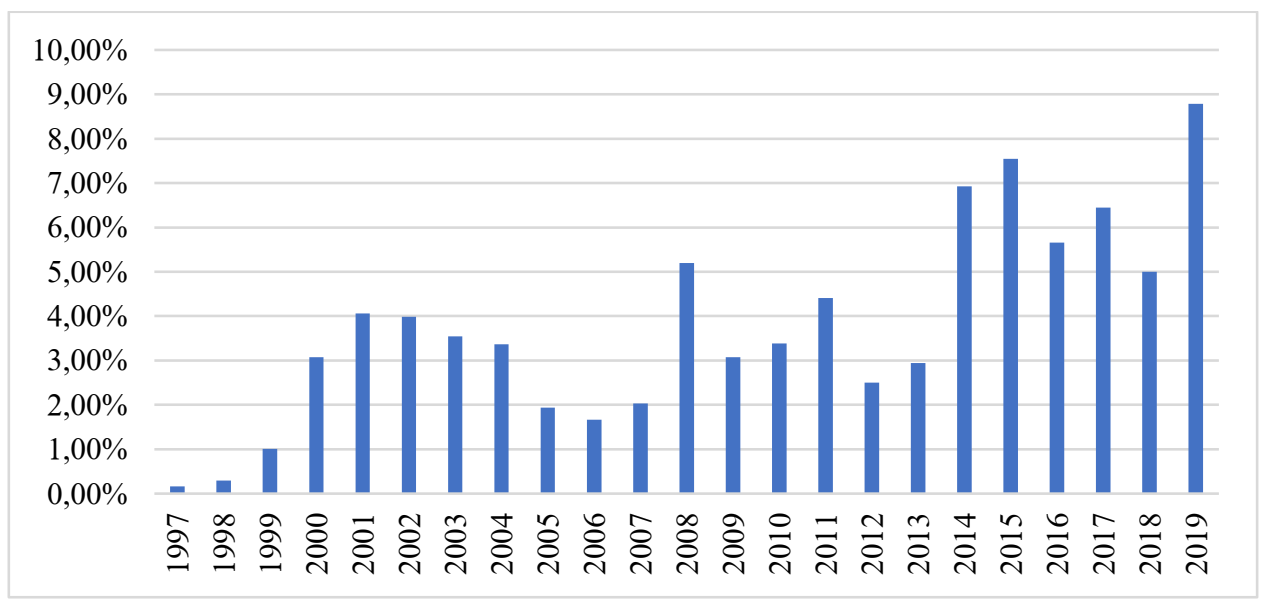

Fig.2. dynamics of the percentage return on LUKOIL shares in the period 1997-2019

Data on the share price is taken at the closing date of the exchange in each reporting year-December 31. Based on the histogram, it is clear that in general there is a trend to increase the annual interest rate, but the yield fluctuates greatly. Such fluctuations in real profitability with a formal increase in dividend payments once again show the relevance of the theoretical problem of dividend policy. This is an example of "blurring" real returns with nominal dividend growth. When adjusted for inflation, the real yield becomes even lower.

\section{Results and Discussion about the stock buyback and a corporate responsibility of the company}

It is worth mentioning another tool of LUKOIL's dividend policy, which is gradually being applied by the company in 2018. In accordance with the company's press release dated August 30, 2018, LUKOIL announced the launch of a share repurchase program totaling up to US \$ 3 billion. The program was launched on September 3, 2018 and was intended to last until December 30, 2022, but on August 20, 2018, the company announced the end of the program due to the fulfillment of its goals [2].

Since the Beginning of the program, LUKOIL Securities Limited (a 100\% subsidiary of the Company) has collectively acquired 13,506,650 ordinary shares and 23,696,806 Depositary receipts in the amount of us $\$ 3$ billion on regulated trading platforms. The purchased securities accounted for $4.96 \%$ of the company's authorized capital [2].

The consequences of buying back almost $5 \%$ of the shares for the company's dividend policy are clear: if a part of the shares is withdrawn from free circulation and their subsequent repayment, the profit per share will inevitably increase. The redemption of shares received under the repurchase program occurred on February $10^{\text {th }}, 2020$. The authorized capital of PJSC LUKOIL was reduced by 22,134,238 ordinary shares based on the decision of the extraordinary General meeting of shareholders of the Company dated 
December 03,2019 , as a result of which the total number of issued ordinary shares of the Company was reduced to $692,865,762$ [2].

A change in earnings per share can lead to two results:

1. If the requirement for constant growth of dividends is formally met, the growth will be nominal, and the real annual return per share in relation to the share price will decrease

2. If the current annual return per share is maintained relative to the share price, the nominal return value will increase (in the absence of market shocks and a sharp drop in the price)

The second scenario looks more likely, since the company has demonstrated full commitment to the declared dividend policy in recent years, and the measures taken in 2019 indicate the desire of management to strictly adhere to the set course. In addition, the share repurchase process can often indicate that the company has an excess of available funds. Because LUKOIL can safely be considered a Mature company, in accordance with the theory of the maturity of the firm's high dividend payments are a normal event [7]. In the context of sanctions pressure and high uncertainty in recent months due to the spread of coronavirus, it is difficult to talk about a potential increase in investment in foreign projects in the short term.

Lukoil Economics \& Finance vice president Alexander Matytsyn also expressed this opinion about the impossibility of expanding the investment program under the current OPEC+ agreements: "Without external restrictions on production, the investment program would be larger, and the current free cash flow would be less"[8].

It should be noted that the dividend yield on LUKOIL shares is one of the highest in the oil and gas sector, which positively affects the demand for the company's shares and the desire of investors to invest in This financial instrument.

It is worth noting, however, that the company's aggressive dividend policy leads to a reduction in opportunities to invest in new projects. Taking into account the OPEC + restrictions, this negative impact does not significantly affect investment activity. However, high dividend payments lead to the annual withdrawal of significant financial resources from the company, equal to $5-8 \%$ of the capitalization. An aggressive dividend policy is also associated with high financial risks, especially against the background of an unfavorable macroeconomic environment, requirements for reducing production within OPEC+, and lower prices for petroleum products due to an oversupply. Given the recordhigh dividend payments in 2019 , the authors doubts whether it is possible to fulfill the obligation to increase dividends annually without taking high financial risks.

Even though the year 2020 is not over yet, we can clearly see a positive trend of the Lukoil stock price on the Moscow exchange. The results are especially outstanding in comparison with other Russian O\&G companies that decided to use another strategy of overcoming the current low oil demand problem.

\section{Conclusion}

The measures taken by Lukoil management team will help to retain current investors, attract investors from competing companies that will look for more profitable objects for investment in the oil and gas sector, maintain the share price at a level acceptable to current shareholders, and protect themselves from unfriendly takeovers from larger state-owned companies in a crisis. Nevertheless, the authors expresses a justified fear that in 2020, even if the proposed measures are implemented without improving the market situation, it will be incredibly difficult to keep the promise of a constant increase in dividend payments. Dividend policy turned to be a valuable instrument for an O\&G company in a plummeting market situation due to the 2 main reasons: ability to sustain a consistent approach and possibility to influence the market stock price via buyback instrument. 


\section{References}

1. S. Ferris, D. Jzvakadze, Y. Lui., Journal of Banking \& Finance, 25 (2020)

2. Lukoil official website, https://lukoil.ru/

3. SPARK-Interfax information and analytical agency (2020), http://www.sparkinterfax.ru/

4. Moscow stock exchange database (2020), https://www.moex.com/

5. Vagit Alekperov's, The presentation of the consolidated financial statements for 2019 (2020), https://lukoil.ru/

6. Management's discussion and analysis of the Lukoil company financial condition and results of operations for 2018-2019 (2019), https://lukoil.ru/

7. E. Dubova, S. Volodin, I. Borenko., Scientific Annals of Economics and Business, 14 (2018)

8. Alexander Matytsyn (Vice President for Economics and Finance), The presentation of the consolidated financial statements for 2019 (2019), https://lukoil.ru/ 